\title{
Personal and shared: the reach of different herbal landscapes
}

\author{
Renata Sõukand $^{\mathrm{a}, \mathrm{b} \varpi}$ and Raivo Kalle ${ }^{\mathrm{a}, \mathrm{c}}$ \\ ${ }^{\text {a }}$ Estonian Literary Museum, Vanemuise 42, 51003 Tartu, Estonia \\ b Institute of Philosophy and Semiotics, University of Tartu, Jakobi 2, 51014 Tartu, Estonia \\ c Department of Food Science and Food Technology, Estonian University of Life Sciences, \\ Kreutzwaldi 2, 51014 Tartu, Estonia \\ $\bowtie$ Corresponding author, renata@folklore.ee
}

Received 25 February 2011, revised 26 June 2011, accepted 15 July 2011

\begin{abstract}
We analyse the use of medicinal plants by local populations from two parishes in central Estonia in the 1930s applying a model of herbal landscape. Our study, based on archived records of traditional ecological knowledge of 11 schoolchildren and 5 adults, compares the individuals' expertise of medicinal plants to the common knowledge of the local community. This shared knowledge, passed on from generation to generation inside the community (ecocultural commons), is distributed unequally among its members. The results of the study show that 65 plant and 3 fungi taxa were used in folk medicine to deal with 49 indications. Further, the study reveals how knowledge on plants was distributed among individuals throughout the local communities and how folk wisdom about medicinal plants was preserved. The individual herbal landscapes of the respondents varied considerably, with the usage of many plants shared by only a few members of the community. Still, the general pattern of the communal herbal landscape follows relatively well the pattern of the plant use in folk medicine in Estonia at the time under review, with just a few exceptions. Hence, every person partakes in the knowledge of the ecocultural commons, whereas the individual share of the community's knowledge is not complete.
\end{abstract}

Key words: medicinal plants, herbal landscape, ecological history, public health, ecocultural commons.

\section{INTRODUCTION}

Research on traditional ecological knowledge (TEK) has been carried out for hundreds of years, especially in indigenous communities. Since the Renaissance, scholars and laymen have documented medicinal plants used by the peasantry in Denmark, Germany, Hungary, and Sweden. There is broad agreement that plant use in folk therapies is a relevant and complex component of local ecological knowledge and that the analysis should also consider cultural, economic, geographical, historical, political, and social aspects (Reyes-García et al., 2004; Vandebroek et al., 2004; Lozada et al., 2006; Jarić et al., 2007; Eyssartier et al., 2008; Lira et al., 2009; Molares \& Ladio, 2009; Thomas et al., 2009). Nowadays European ethnobotanists analyse community-shared and traditional knowledge of plants and their usage (ecocultural commons), which developed in the interactions 
of humans with the landscape surrounding them (Svanberg et al., 2011). The research on ecocultural commons includes how humans perceive and place plants inside their culture and how biological resources are locally managed. In doing so, ethnobotanists emphasize the need for scientific rigour and the integration of different methodological approaches (Etkin, 1993; Waldstein \& Adams, 2006). In particular, they promote a hypothesis-driven research and quantitative analysis for overcoming the shortcomings of descriptive inventories of plant use (Vandebroek, 2010).

To facilitate hypothesis-driven research on the usage of medicinal plants, we put forward a proposal to add to the traditional ecological approach the model of the 'herbal landscape', defined as a cognitive field of plants that are used to treat or prevent diseases by local residents who live within specific cultural and climatic zones and know about these medicinal plants and/or share a specific plant knowledge within a certain group of people (Sõukand \& Kalle, 2010a). The 'herbal landscape' is a cognitive field - the term cognitive refers to the dynamic process of knowing how to make use of natural resources (cf. cognitive map, Tolman, 1948) and field represents the environmental space covered by this specific knowledge. In our earlier writings we discussed natural and cultural boundaries of the herbal landscape (Sõukand \& Kalle, 2010b) and its theoretical premises (Sõukand, 2010) and outlined the shifts that have occurred within it during the last century (Sõukand \& Kalle, 2011).

Landscape paradigms have often been applied when explaining the complex circumstances of how humans interact with their natural surroundings. For example, the Italian ecologist Farina (2006: 5), when comparing several definitions of landscape from different cultural and scientific approaches, finds the most suitable one defining landscape 'as a piece of land which we perceive comprehensively around us, without looking closely at single components, and which looks familiar to us' (the original definition is from Haber, 2004). He continues, 'when the organism is man, the landscape is a broad area composed of a mosaic of patches, ecotopes and cultural elements' (Farina, 2006: 5). In connecting the diverse definitions of landscape, Farina developed his quite broad model of a cultural landscape emphasizing that 'the relationships between human activity and the environment have created ecological, socio-economic, and cultural patterns and feedback mechanisms that govern the presence, distribution, and abundance of species assemblages' (Farina, 2000: 113).

By adopting Uexküll's concept of Umwelt, Farina divides the cognitive landscape into three types. First, there is the neutrality-based landscape that acts like a background of noise, which the sense organs cannot distinguish or decode. Second, the individually-based landscape is the part of the surrounding that our body can decipher, implicating that the individually based landscape incorporates cognitive mechanisms. Finally, there is an observer-based landscape, which Farina (2006: 16) explains as 'the piece of the real world perceived by people by using a cultural filter. [..] experience and learning are stocked into temporary memory that does not survive the organism's death'. This landscape, however, can be experienced or transferred through cultural mechanisms. The observer-based 
landscape corresponds with the personal herbal landscape acquired through the cultural filter, individual experience, and learning; it is preserved throughout the person's life as long as the natural conditions support and the needs for the medication require the herbal resources.

Here we present a selected example from archival data on Estonian herbal medicine for deepening and corroborating our theoretical approach and reflecting upon the differences between the personal herbal landscape and those shared within a community. We argue that the personal herbal landscape reflects the immediate needs of individuals and, thus, covers only part of the communal knowledge, whilst the herbal landscape as an ecocultural commons (i.e., knowledge shared and transferred at a specific location from generation to generation) preserves the ecological knowledge of a region through time. In general, the ecocultural heritage of Estonia makes a perfect example for our case study, comparing the individual expertise to the shared traditional knowledge of rural communities on the usage of medicinal plants.

\section{METHODS}

For the present study we used written records of the ecological knowledge of two neighbouring parishes, Ambla and Järva-Madise in central Estonia, from the 1930s. The text records were collected by the schoolteacher and amateur biologist Teet (until 1938 Julius) Lunts ${ }^{1}$ (1902-1941) and came mainly from his pupils who originated from these two parishes. Lunts sent two collections of reports (Vilbaste TN 2: 324-382), including (among other plant knowledge) the medicinal use of plants, to the schoolteacher and publicist Gustav Vilbaste (1885-1967), the first Estonian ethnobotanist. These reports now belong to Gustav Vilbaste's collection of ethnobotanical manuscripts (Vilbaste TN), part of which has been digitized for the Historical Estonian Herbal Medical Database (HERBA, created by Sõukand and Kalle in 2008). Although those reports did not contain dried plant samples, most of the species were confirmed by reliable amateur

1 Teet Lunts was headmaster of a six-year primary school at Lehtmetsa-Risti, situated at the border of these two parishes, and taught there all classes except girls' handiwork from 1928 to 1938. Thereafter until his execution in 1941 by the retreating Soviet Army, he was headmaster of the neighbouring primary school at Seidla. Besides his duties as a schoolteacher, Lunts completed botanical training at the University of Tartu and was the first (amateur) botanist in Järvamaa, who mapped the distribution of rare plant species and inspected plant communities according to scientific standards (Rannap, 1998). After 1930 Lunts published 35 floristic notes and articles in the Estonian nature journals Eesti Loodus [Estonian Nature] and Loodusevaatleja [Nature Observer], for example, a study about the plant cover of eskers of North Estonia (Lunts, 1937a, 1937b) and another one on the riverplain forest at the Jänijõgi River (Lunts, 1938). Since 1919 he was a devoted correspondent of Vilbaste, discussing all aspects related to plants and nature conservation (EKLA F 152, M 26:6). Lunts was also a distinguished correspondent of the Estonian Folklore Archives, providing the greatest collection of folklore of Järvamaa. Among other folklore he sent there in 1937 a copy of part of the data he had originally sent to Vilbaste (ERA II 167, pp. 167-185). 
botanists, e.g. Lunts himself, or were assigned a folk name that was commonly used in this area (for credibility of plant identification, see Łuczaj, 2010). Only two reports in this collection contain unidentifiable plant names and, therefore, were left out of our analysis.

Of the 16 individuals questioned about the usage of plants, eleven were Lunts' pupils and the other five were local knowledgeable persons. These individual collectors' expertise will be compared to the aggregated knowledge of the community for a better understanding of the herbal landscape under study. We also included into the analysis a set of community plant knowledge collected by Lunts but sent without indicating the source other than it was collected with the help of his pupils. As Lunts left no records about his methodology, it is rather difficult to reconstruct what methods and standards were used for the reports sent to Vilbaste. We can guess how he structured his questionnaire and what questions he might have asked based on the pupils' responses. Further, we do know whether he requested to be shown the plant when the taxon could not be unequivocally recognized. Although Lunts did not mention it explicitly, he apparently also personally interviewed adults with a general questionnaire provided by Vilbaste. One person he certainly questioned in summertime was Miina Veiderpass, an elderly local healer. Separately, he also questioned pupils from the oldest (fourth to sixth) grades at the Lehtmetsa-Risti school. The exact number and age of the pupils questioned is unknown, but it is known that in 1919 the school had 38 pupils and in 1938 there were 46 pupils (Kvell, 2003). As he grouped their answers together without naming the sources or counting the responses, we cannot know which individuals used which plants.

The majority of the responses dealt with how a plant was used as a medicine or a dye or how its magical properties were employed. Lunts assigned Vilbaste's questionnaire about plant use to the pupils as homework and expected answers in the form of an essay, assuming creative results, not merely a list of plants and diseases. The pupils completed their personal assignments in wintertime (the date of 14 January 1931 was added to the essays of several pupils). Most of the data submitted by Lunts are given as a descriptive text or in the form of an individual pupil's essay. Lunts also provided an extensive collection of vernacular plant names and their Latin equivalents.

For the purpose of analysing the texts, we divided all responses into use-reports. A use-report is defined as an 'event resulting from the combination of the [following] three variables: informant $i$ mentions the use of the species $s$ in the use-category $u$ ' (Tardì \& Pardo-de-Santayana, 2008). In the following we first analyse the representation of the plant taxa and their division according to the habitat and hemeroby level, as well as the distribution of the diseases on the level of the shared community TEK, including all use-reports dealing with the medicinal use of plants. Then we review the herbal landscapes of selected respondents and their relative importance within the community herbal landscape and, where appropriate, their position according to the general knowledge about the ecocultural commons in Estonia, as specified by HERBA. 


\section{HERBAL LANDSCAPE AS AN ECOCULTURAL COMMONS}

Lunts collected 175 use-reports on how plants were utilized for medicinal purposes, reflecting the use of 65 plant and 3 fungi $^{2}$ taxa against 49 health indications. While the list of all plants named by the respondents of Lunts is numerous (Table 1), the list of the most frequently used taxa is rather short. Only very few plants were listed by the majority of the respondents, and none of them was listed by all (Table 2). The plants are all assigned to a dominant habitat and sensitivity to humans: anthropophytes (plants depending on human activity), apophytes (plants preferring human activity), hemeradiophores (plants indifferent to human activity), and hemerophobes (plants fearing human activity) (based on Kukk, 1999).

The use-reports were divided according to the plant's habitat (Fig. 1), sensitivity to human impact (Fig. 2), and diseases cured (Fig. 3). As a rule, in the 1930s rural homes in Estonia were surrounded by semi-natural meadows. Therefore, it will be no surprise that a large proportion $(39 \%)$ of the use-reports reflect on the use of plants growing on meadows, whereas only $9 \%$ of the plants reported grow in gardens and courtyards. The reason here may lay in the fact that until the early 1920s gardening was not much practised on the territory of present Estonia (for more details see Sõukand \& Kalle, 2010b). As the area under study is situated in central Estonia, which features a geobotanical sub-district of forest and wetlands (Laasimer, 1965: 291), relatively high percentages of the plants were collected from wetlands (23\%) and forested areas including trees and bushes (23\%) (Fig. 1). Such a relatively even distribution of utilized plants helps to assure the ecological sustainability of how the botanical resources were used and simultaneously covers a wide nomenclature of plants available in different ecotopes.

Regional division of the medicinal plants according to their sensitivity to human impact differs notably from the hemeroby distribution on the country level at the same time (Fig. 4). Comparing Figs 2 and 4, we see that anthropophytes were used merely half as often and hemeradiophores were used almost twice as often as they were utilized on the country level, while the use of apophytes and hemerophobes was almost the same as their country-level utilization. Such preference for the plants that do not depend on human activity requires a profound knowledge of wild plants.

All together, $28 \%$ of the cases reflect the use of medicinal plants for indications mentioned only once or twice, covering a wide variety of health conditions occasionally treated by plants (the full list is provided in the abbreviation section for Table 1). As expected, most treated conditions were related to the cold and wet climate: $12 \%$ of the use-reports treated cough and $9 \%$ tuberculosis, making those two the most common illnesses fought with plants in this region. Cough was one of the most common diseases among children in the wintertime, and tuberculosis was a quite common disease in Estonia until the 1970s. Rheumatic diseases (10\%) and straining (7\%), which are widespread health problems in wet

2 In the Estonian folk categorization plants and fungi were not differentiated, being both considered plants. Hereafter the term 'plants' is used according to the folk categorization. 


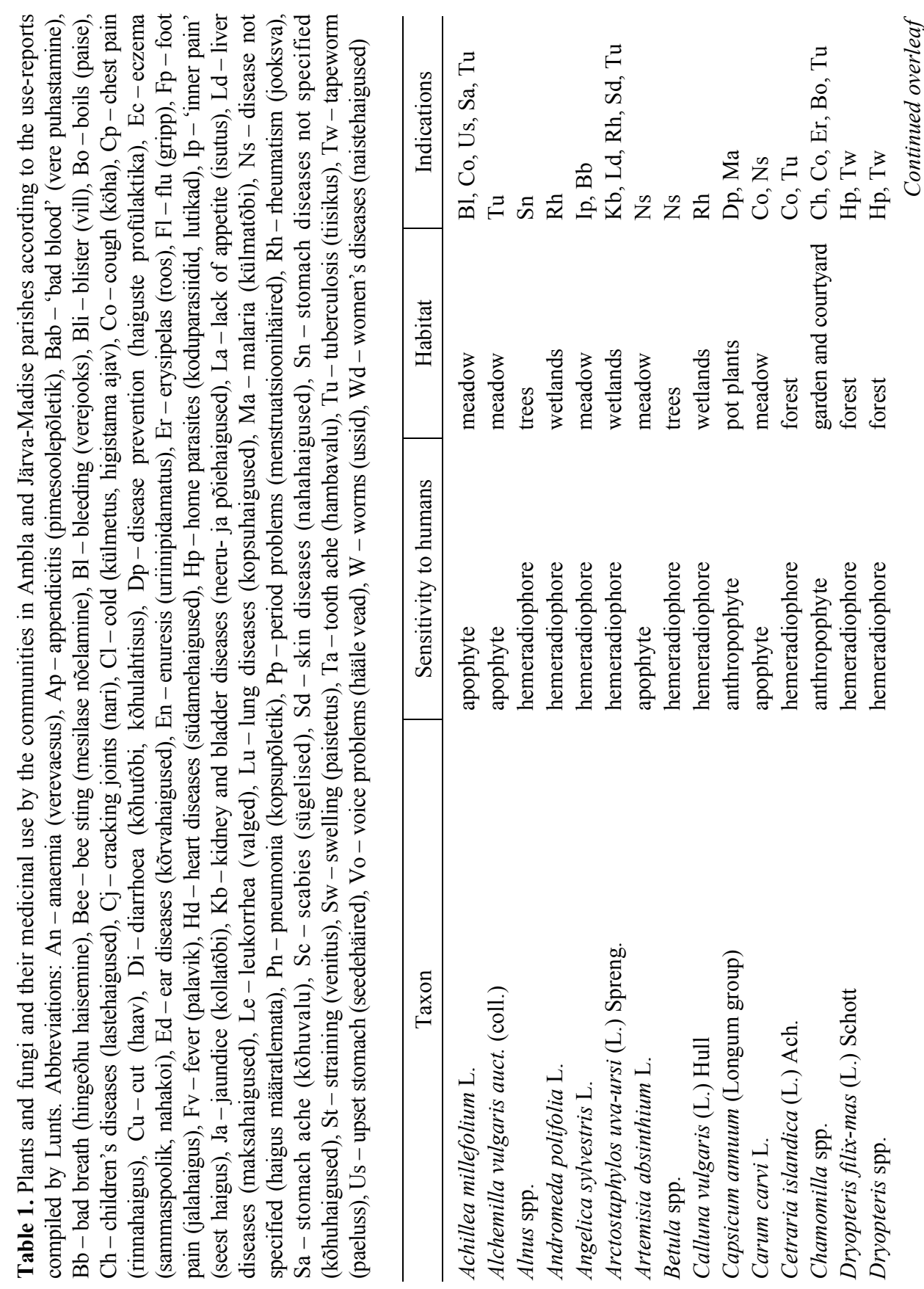




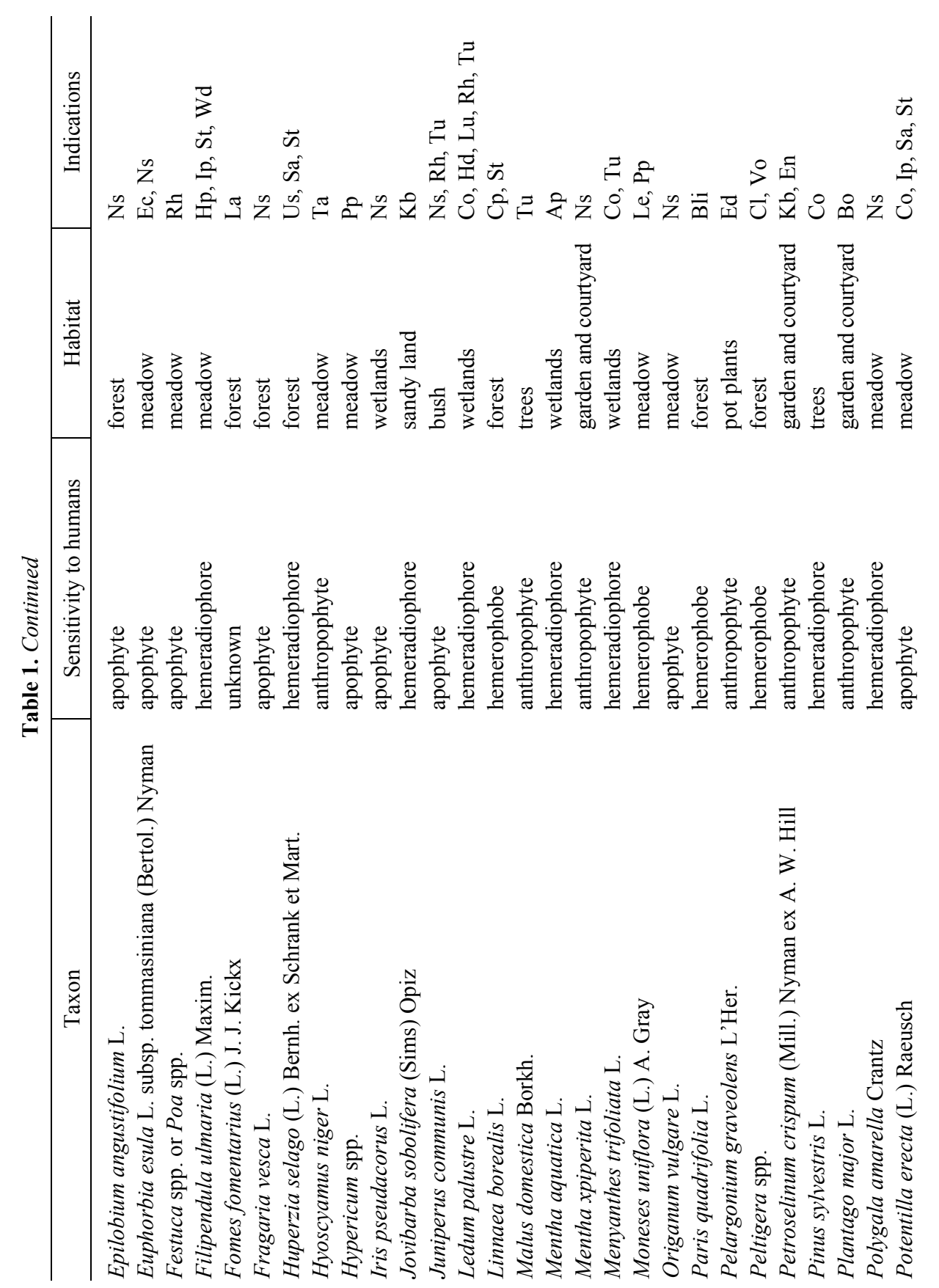




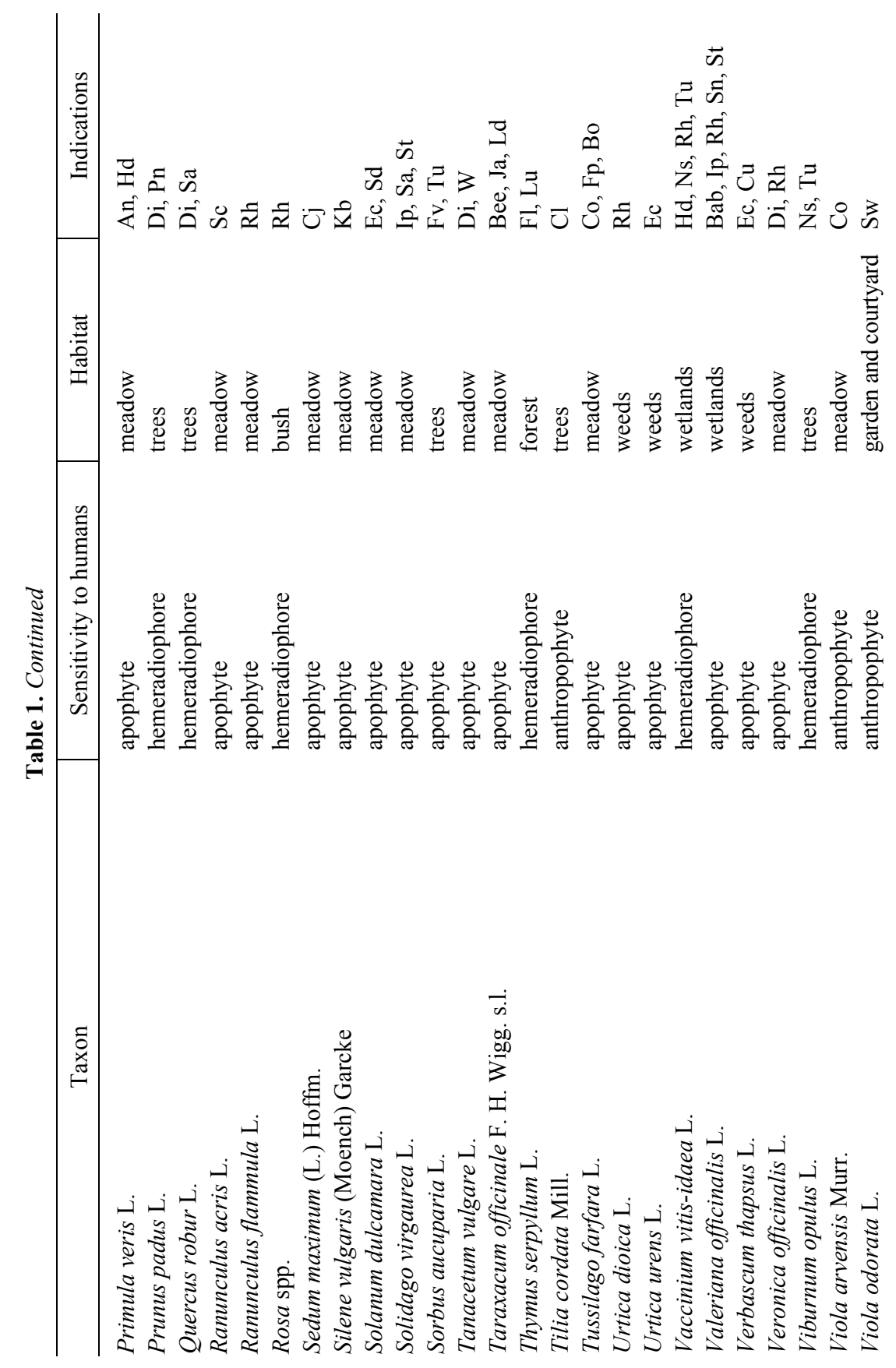


Table 2. Plants dominating in the community-level herbal landscape according to the use-reports compiled by Lunts

\begin{tabular}{l|c}
\hline \multicolumn{1}{c|}{ Taxon } & No. of use-reports \\
\hline Achillea millefolium L. & 13 \\
Arctostaphylos uva-ursi (L.) Spreng. & 11 \\
Chamomilla spp. & 9 \\
Vaccinium vitis-idaea L. & 8 \\
Ledum palustre L. & 8 \\
Solidago virgaurea L. & 8 \\
Potentilla erecta (L.) Raeusch & 7 \\
Valeriana officinalis L. & 5 \\
Pelargonium graveolens L'Her. & 4 \\
Filipendula ulmaria (L.) Maxim. & 4 \\
Taraxacum officinale F. H. Wigg. s.l. & 4 \\
Cetraria islandica (L.) Ach. & 4 \\
Huperzia selago (L.) Bernh. ex Schrank et Mart. & 4 \\
Tussilago farfara L. & 3 \\
Linnaea borealis L. & 3 \\
Menyanthes trifoliata L. & 3 \\
Juniperus communis L. & 3 \\
Dryopteris filix-mas (L.) Schott. & 3
\end{tabular}

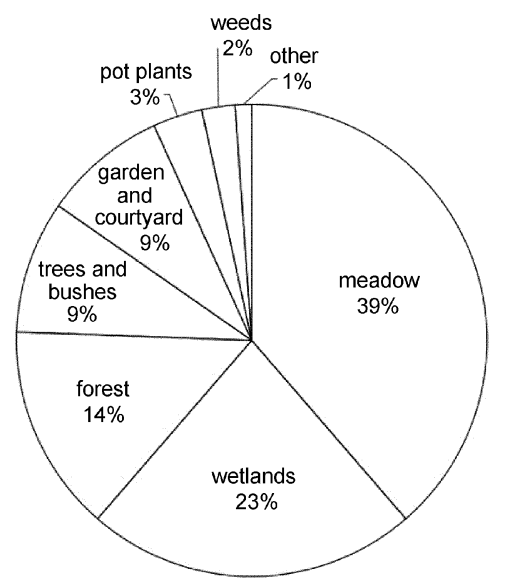

Fig. 1. Medicinal plants on the community level by plant habitat according to the use-reports compiled by Lunts.

and cold places, are also among the most often mentioned diseases in the corpus of Estonian TEK. Further, various diseases related to intestinal problems (stomach pain, diarrhoea, inner pain, etc.) were often mentioned by schoolchildren to be treated with plants. This refers to poor hygiene and the lack of food during the time preceding the questioning. 


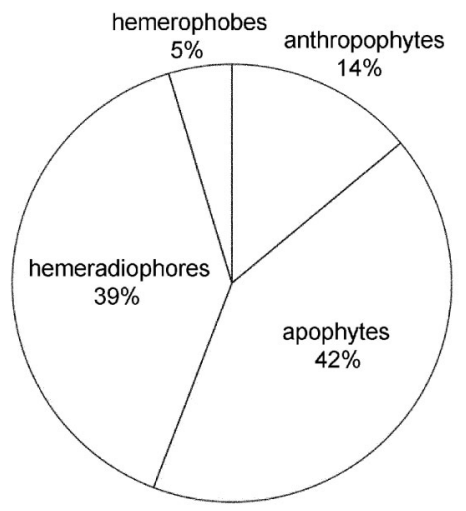

Fig. 2. Distribution of medicinal plants by their sensitivity to human impact according to the usereports compiled by Lunts.

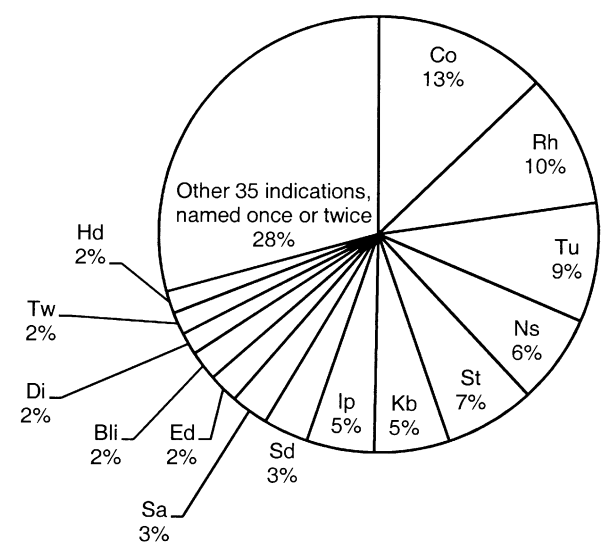

Fig. 3. Frequency of the diseases cured with plants on the community level according to the usereports compiled by Lunts. For abbreviations see Table 1.

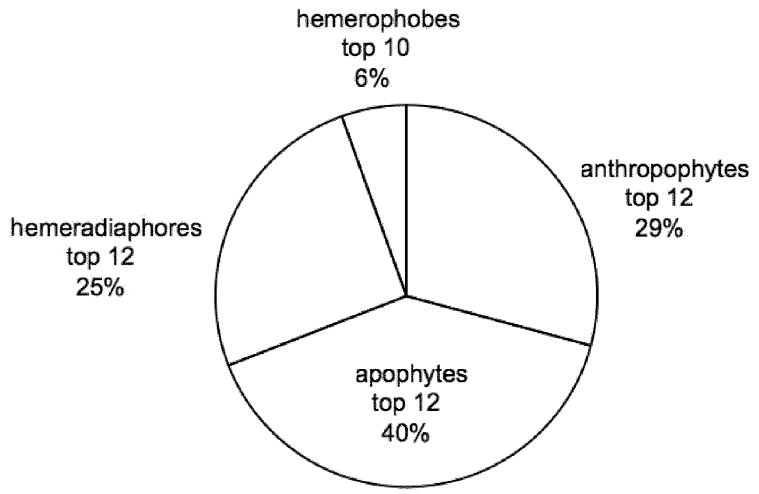

Fig. 4. Distribution of most often mentioned plants in the use-reports by hemeroby on the country level in 1921-1940 (based on data from Sõukand \& Kalle, 2011). 


\section{INDIVIDUAL HERBAL LANDSCAPES}

Erna Ader, the most knowledgeable of all pupils and one of the two female pupils who completed the assignment, knew 11 medicinal plants (see Table 3 for pupils' responses). The knowledge on how to consume these plants was shared with other respondents, except for two plants - Plantago major L. and Polygala amarella Crantz. The former was applied against cuts and boils (although other respondents in Lunts' sample do not mention it, the plant is well known as a remedy against these conditions in Estonia and internationally). However, Ader's usage of $P$. amarella for stupidity is unique in the database. The other diseases that she listed were widely known and cited, varying in the difficulty of condition, as traditionally treated by plants. For several diseases she mentioned the use of different plants (e.g., cough and tuberculosis treated with Juniperus communis L.,

Table 3. Plants and health indications mentioned by the schoolchildren in their individual herbal landscapes according to the use-reports compiled by Lunts. Informants: AV - Aksel Vink, EK - Edgar Kokaselts, EN - Elfriide Nicopensius, ErN - Erich Nuiamäe, EA - Erna Ader, LS - L. Sooberg, NN - name unknown, RP - Robert Pelz, VK - Verner Kadabi. For abbreviations of indications see Table 1

\begin{tabular}{|c|c|c|c|c|c|c|c|c|c|c|c|}
\hline Taxon & AV & EK & EN & ErN & EA & LS & NN1 & NN2 & NN3 & $\mathrm{RP}$ & VK \\
\hline $\begin{array}{l}\text { Achillea millefolium } \mathrm{L} \text {. } \\
\text { Alchemilla vulgaris auct (coll.) }\end{array}$ & $\mathrm{Co}$ & Co & & Co & Co & & Co & $\begin{array}{l}\mathrm{Tu} \\
\mathrm{Tu}\end{array}$ & & $\mathrm{Sa}$ & $\mathrm{Co}$ \\
\hline Arctostaphylos uva-ursi (L.) Spreng. & & & $\mathrm{Kb}, \mathrm{Sd}$ & & $\mathrm{Kb}$ & $\mathrm{Kb}$ & & $\mathrm{Rh}$ & & & $\mathrm{Kb}$ \\
\hline Calluna vulgaris (L.) Hull & & & & & & & & $\mathrm{Rh}$ & & & \\
\hline Carum carvi $\mathrm{L}$. & & & & & & & & & Co & & \\
\hline Cetraria islandica (L.) Ach. & & & & & $\mathrm{Co}$ & & & & & & \\
\hline Chamomilla spp. & Co & Co & & Co & & & Bo & $\mathrm{Tu}$ & $\mathrm{Co}$ & & \\
\hline Dryopteris spp. & & & & & & & & & Tw & & \\
\hline $\begin{array}{l}\text { Huperzia selago (L.) Bernh. } \\
\text { ex Schrank et Mart. }\end{array}$ & & & & & & & St & & & & \\
\hline Jovibarba sobolifera (Sims) Opiz & & & & & $\mathrm{Kb}$ & & & & & & $\mathrm{Kb}$ \\
\hline Juniperus communis L. & & & & & $\mathrm{Tu}$ & & & & & & Ns \\
\hline Ledum palustre $\mathrm{L}$. & & $\mathrm{Tu}$ & & & & $\mathrm{Lu}$ & $\mathrm{Tu}$ & & & Co & \\
\hline Menyanthes trifoliata $\mathrm{L}$. & & & & & Co & & & & & & Co \\
\hline Pelargonium graveolens L'Her. & $\mathrm{Ed}$ & $\mathrm{Ed}$ & & & & & Ed & & & $\mathrm{Ed}$ & \\
\hline Plantago major $\mathrm{L}$ & & & & & Bo & & & & & & \\
\hline Polygala amarella Crantz & & & & & Ns & & & & & & \\
\hline Potentilla erecta (L.) Raeusch & & Co & & $\mathrm{Sa}$ & Ip & & & & & & Ip \\
\hline Quercus robur L. & $\mathrm{Sa}$ & & & & & & & & & Di & \\
\hline Solanum dulcamara L. & & & & & & & & & & & $\mathrm{Sd}$ \\
\hline Solidago virgaurea $\mathrm{L}$. & & & & $\mathrm{Sa}$ & Ip & St & & St & Ip & & Ip \\
\hline Sorbus aucuparia L. & & & & & & & & & & & $\mathrm{Tu}$ \\
\hline Tilia cordata Mill. & & & & & & & & & & $\mathrm{Cl}$ & \\
\hline Vaccinium vitis-idaea $\mathrm{L}$. & $\mathrm{Rh}$ & $\mathrm{Rh}$ & $\mathrm{Tu}$ & & & & $\mathrm{Rh}$ & $\mathrm{Rh}$ & & & \\
\hline Valeriana officinalis L. & & & St & $\mathrm{Sn}$ & & $\mathrm{Rh}$ & & & Ip & & \\
\hline Viburnum opulus L. & & & & & $\mathrm{Tu}$ & & & & & & Ns \\
\hline
\end{tabular}


Viburnum opulus L., Cetraria islandica(L.) Ach., Achillea millefolium L., Menyanthes trifoliata L.; kidney and bladder diseases treated with Jovibarba sobolifera (Sims) Opiz and Arctostaphylos uva-ursi (L.) Spreng., etc.), while according to her boils were to be treated only with P. major. As Ader refers to plants that originated from different habitats, her individual herbal landscape encompasses a relatively wide geographical area. Notably, half of the plants she mentioned prefer limited human activity, although none of them is a hemerophobe.

Verner Kadabi, a male pupil, showed the next most profound knowledge of the herbal landscape. He listed ten plants used to cure six widely known indications. Three of these plants (J. sobolifera, Quercus robur L., and Sorbus aucuparia L.) were shared only with a few respondents, although the last two plants have been widely used as medicinal plants in the whole country. Other plants in his report were more widespread in the herbal landscape shared by the local community. For Viburnum opulus L. and J. communis, Kadabi did not know the application, although both plants were widely used on the country level. Indeed, J. communis was one of the most popular medicinal plants in Estonia in the 19th century (Sõukand \& Kalle, 2008).

None of the plants was mentioned by all the schoolchildren. All the plants they listed were shared with other respondents, except two plants named by Erna Ader (Plantago major and Polygala amarella). Usually pupils named one plant per indication, except for cough, where as a rule two different taxa were used (predominantly A. millefolium and Chamomilla spp.), with the exception of one pupil who knew that one plant could be used against two different groups of diseases (A. uva-ursi against stomach diseases and kidney and bladder diseases). Although the usages of plants were often overlapping, the modes of the preparation of the remedies and vernacular names of the diseases and plants varied considerably. Thus, collaborative work and/or an exchange of the individual expertise can be excluded as reasons for the repetition.

The number of plant taxa known by an individual pupil varies between 3 and 11. Considering that the assignment was completed during wintertime, diseases related to cold, such as cough and tuberculosis, dominated. Also, the relatively wide use of potted plants supports the idea of dependence on the season. As the pupils' reports were home assignments, they probably reflected the plants their families actively used during wintertime, covering not only their personal knowledge, but also the herbal landscape of their households.

In addition to the schoolchildren, Lunts interviewed five adults, three of whom he called local healers. The most knowledgeable of them was Miina Veiderpass (1851-1932), who was questioned in the last summer of her life. In her youth she was a domestic servant for Alexander Peter Ernst von Lilienfeld (1831-1909), the landlord of Albu manor. She indicated that von Lilienfeld knew many plants and collected and sent plants for sale to Germany, and that she had learned the usage of some plants from him. Later she became a respected plant-healer in her community. The interview with her revealed her knowledge on the use of 33 plants, of which 15 were unique and not used by any other respondent; among them one usage of a plant (Viola odorata L.) was unique in HERBA. In most cases 
she knew one plant per health problem; only eight plants were used to treat two different conditions.

In general, her usage of medicinal plants follows the pattern of the shared herbal landscape. Veiderpass reported the treatment of 30 different conditions whereas other respondents did not mention more than 19 of these conditions, probably because most of these were more complicated and did not belong to the canon of the shared herbal landscape (like anaemia, appendicitis, 'bad blood', children's diseases, erysipelas, etc.). The most severe diseases were certainly the ones against which the peasants needed the help of the landlord. The landlord's knowledge of alien medicinal plants, which Veiderpass probably had learned in her youth, included Mentha xpiperita L., Chamomilla spp., and Hyoscyamus niger L. She also recalled collecting Tussilago farfara L. as a duty for the manor. With the local community she shared the use and the name of Solidago virgaurea L. (arnica, referring to an alien plant Arnica montana L. not growing in Estonia). However, the use of arnica was by that time also widely promoted in the popular literature (Sõukand \& Raal, 2008). Further, the whole community shared knowledge about an alien plant used by Veiderpass (Chamomilla spp.), although her use differed considerably from the one of the local community - skin and children's diseases by Veiderpass versus cough, tuberculosis, and boils by the pupils. Thus, neither of these plants verifies her direct influence on the communal herbal landscape.

Another local healer, a Mr Brokman, was 72 years old (probably born in 1859) when Lunts interviewed him together with his wife (about whom nothing else is known). The Brokman couple presented a rather short list of plants (in total 8 plants). They reported healing women's diseases (as does Veiderpass) and also enuresis (also reported by another adult respondent). They were the only ones using Hypericum sp., Veronica odorata L., and Moneses uniflora (L.) A. Gray. Their utilization of Verbascum thapsus L. and M. uniflora was unique in HERBA. Lunts mentioned that he was planning to visit the Brokmans again in order to collect more data (indicating that the information he had received was not complete), but unfortunately he did not do so. This shows that their responses were not the whole individual herbal landscape, but merely the part they could reproduce at the moment of being interviewed.

Although acknowledged as a healer, Jaan Enger, a local potter born in Latvia in 1880 , used plants mostly to heal animals and mentioned only three species that were applied against human diseases. The reason here may partly lay in the fact that he was of non-Estonian origin ${ }^{3}$ and, mainly, in the fact that he had a full-time job that was not related to plants, or a combination of both. Maybe, he never had a chance to learn local plants so that he could use them for healing humans.

Other two adult members of the local community whom Lunts interviewed knew relatively few plant uses when contrasted to the schoolchildren's answers: they only knew the use of three plants each. Nevertheless, all of them had an individual 'favourite' plant, used for several purposes.

3 Jaan Enger acknowledged that the use of roots of Rosa spp. against rheumatic diseases originated in Latvia. 


\section{CONCLUSIONS}

In this study, the individual herbal landscape of every respondent differed considerably from those of the other respondents, and many plants were shared by only a few members of the community. Still, the general pattern of the communal herbal landscape follows relatively well the pattern of the medicinal plant use in Estonia at the time under review, with just a few exceptions. Hence, every person partook in the knowledge of the ecocultural commons whereas the individual share of the community's knowledge was not complete. Although Lunts' sampling is not adequate for drawing far-reaching conclusions, we can at least outline some factors that influence the distribution of the herbal landscape within the population.

Task-specific plant knowledge is a widely known fact. Müller-Schwarze (2006) documented the different ways in which women and men relate to the environment. Consequently, they also differ in their knowledge about plants (cf. also Pieroni et al., 2002). Although Estonians traditionally had different tasks in their households depending on gender and age, nowadays they are nearly equalized and the differences are more conditioned by other criteria such as educational level, wealth, family status, health, etc. Still, at the time of Lunts' interview plant knowledge differed, as women (and children) had a better knowledge about herbs, flowers, and cultivates, while men were more interested in trees and bushes (Michelson, 1935).

Recognizable plant features are present only in certain seasons (except for evergreen trees and pot plants grown on the window sill). Working (and usual plant-picking) sites were normally visited in the course of seasonal activities. As the pupils' essays were written in wintertime, the nomenclature of the species can be induced by this seasonal constraint. Thus seasonality plays an important part in Lunts' recorded herbal landscapes.

Bringing the human dimension into landscape models allows us to develop several conceptual frameworks that can help to model and analyse interactions of humans with their environment. As such, it takes its unique position within the scope of medical ethnobotany and presents a useful theoretical tool for future international research about medicinal plants. In its (future) usefulness it is comparable to the therapeutic landscape, developed by health geographers, as another remarkable tool for the analysis of the contribution of physical, social, and symbolic environments to physical and mental health and well-being (Gesler, 2009).

As previously mentioned, a community shares the landscape it is settled in as well as the knowledge of its use. Thus we can speak of a community-shared herbal landscape, assuming that it constitutes the individual knowledge of every person in the community. If we draw a correlation with folklore, the landscape also has a spatial component (heterogeneous, fragmentary, episodically remembered, etc.). In analysing the community-shared herbal landscape according to the plants used, their habitat and sensitivity to human impact may reveal the composition of the landscape and the proportion of the plants utilized in the whole community. Further, 
the way a community accepts a new herb into the cultural landscape, or how another herb acclimatizes in the natural landscape, is the measure of sustainability and flexibility of healing traditions in the given society.

Although the conclusions outlined above are preliminary ones, as the sample of these historical data is rather small and methods of collection quite unclear, we still can draw some interesting conclusions that help to understand the importance of an individual herbal landscape within the shared knowledge of the ecocultural commons.

Once created, different elements of the herbal landscape remain with the community through someone's personal herbal landscape as long as there is a need for healing and/or resources available. Personal landscapes were overlapping only to some extent, covering probably the areas most important for the individual's household. Although a healer or a person with a special education may possess a broader knowledge of plant use over time than regular members of the community, he or she still does not cover all the overall knowledge shared by the local community. Considering that this knowledge was rather common in Estonia, all the members had a specific part in preserving the ecocultural commons. The knowledge stored within the community is dispersed among its members, staying alive as long as there is someone who needs it, knows how to use a specific plant, and is able to train others in its use.

To confirm the validity of these conclusions more research has to be done in contemporary rural communities. This requires standardized interviews in different settings (e.g. at home in wintertime, in the field in summertime) and visiting different plant habitats. The future research shall cover a broader sample to understand the effects of gender, age, and occupation on the maintenance of individual herbal landscapes.

\section{ACKNOWLEDGEMENTS}

The authors acknowledge for supporting this research the Governmental Research and Development programme 'Estonian Language and Cultural Memory' (EKKM09-84) and the European Union through the European Regional Development Fund (Centre of Excellence CECT). The authors' special thanks go to Sabine Brauckmann and Dolly Jørgensen for valuable comments and editing the manuscript prior to submission.

\section{ORIGINAL SOURCES}

EKLA F 152, M 26:6 = Correspondence of J. Lunts with G. Vilbaste. 1919-1938. Stored at the Estonian Literary Museum. 18 letters.

ERA $=$ Folklore collection of the Estonian Folklore Archives. 1927-1944. Stored at the Estonian Literary Museum. 265098 pages, 708 bindings.

Vilbaste TN $=$ Gustav Vilbaste's collection of ethnobotanical manuscripts. 1907-1966. Stored at the Estonian Literary Museum. 8319 pages, 11 bindings. 


\section{REFERENCES}

Etkin, N. L. 1993. Anthropological methods in ethnopharmacology. J. Ethnopharmacol., 38, 93-104.

Eyssartier, C., Ladio, A. H. \& Lozada, M. 2008. Cultural transmission of traditional knowledge in two populations of north-western Patagonia. J. Ethnobiol. Ethnomed., 4, 25.

Farina, A. 2000. The cultural landscape as a model for the integration of ecology and economics. Bioscience, 50, 313-320.

Farina, A. 2006. Principles and Methods in Landscape Ecology. Toward a Science of Landscape. Springer, Netherlands.

Gesler, W. M. 2009. Therapeutic landscapes. In International Encyclopedia of Human Geography (Kitchin, R. \& Thrift, N., eds), pp. 229-230. Elsevier, Oxford.

Haber, W. 2004. Landscape ecology as a bridge from ecosystems to human ecology. Ecol. Res., 19, 99-106.

Jarić, S., Zorica, P., Mačukanović-Jocić, M., Djurdjević, L., Mijatović, M., Karadžić, B., Mitrović, M. \& Pavlović, P. 2007. An ethnobotanical study on the usage of wild medicinal herbs from Kopaonik mountain (central Serbia). J. Ethnopharmacol., 111(1), 160-175.

Kukk, T. 1999. Eesti taimestik [Vascular plant flora of Estonia]. Teaduste Akadeemia Kirjastus, Tallinn.

Kvell, K. 2003. Mägede mõhnastiku matkarada. http://www.hot.ee/loodusmatkale/jalgsi/magede.html (accessed 13.07.2011).

Laasimer, L. 1965. Eesti NSV taimkate. Valgus, Tallinn.

Lira, R., Casas, A., Rosas-López, R., Paredes-Flores, M., Pérez-Negrón, E., Rangel-Landa, S., Solís, L., Torres, I. \& Dávila, P. 2009. Traditional knowledge and useful plant richness in the Tehuacán-Cuicatlán valley, Mexico. Econ. Bot., 63, 271-287.

Lozada, M., Ladio, A. \& Weigandt, M. 2006. Cultural transmission of ethnobotanical knowledge in a rural community of northwestern Patagonia, Argentina. Econ. Bot., 60, 374-385.

Łuczaj, J. L. 2010. Plant identification credibility in ethnobotany: a closer look at Polish ethnographic studies. J. Ethnobiol. Ethnomed., 6, 36.

Lunts, J. 1937a. Põhja-Eesti vallseljakute taimkattest. The vegetation of the North-Estonian ridges. Eesti Loodus, 5(3), 104-108.

Lunts, J. 1937b. Põhja-Eesti vallseljakute taimkattest II. Tapa ümbruse vallseljakud. The vegetation of the North-Estonian eskers. Eesti Loodus, 5(4), 140-144.

Lunts, J. 1938. Uhtlamm-mets Jänijõel. Riverplain forests near the Jänijõgi. Eesti Loodus, 6(3), $124-128$.

Michelson, K. 1935. Viivuke taimeteadusliku "keelepaja" juures. Loodusvaatleja, 1, 6-9.

Molares, S. \& Ladio, A. 2009. Ethnobotanical review of the Mapuche medicinal flora: use patterns on a regional scale. J. Ethnopharmacol., 122(2), 251-260.

Müller-Schwarze, N. 2006. Antes and Hoy Día: plant knowledge and categorization as adaptations to life in Panama in the twenty-first century. Econ. Bot., 60, 321-334.

Pieroni, A., Nebel, S., Quave, C., Münz, H. \& Heinrich, M. 2002. Ethnopharmacology of liakra: traditional weedy vegetables of the Arbëreshë of the Vulture area in southern Italy. J. Ethnopharmacol., 81, 165-185.

Rannap, H. 1998. Eesti kooli biograafiline leksikon [Biographical Lexicon of Estonian School]. Eesti Entsüklopeediakirjastus, Tallinn.

Reyes-García, V., Byron, E., Vadez, V., Godoy, R., Apaza, L., Pérez Limache, E., Leonard, W. R. \& Wilkie, D. 2004. Measuring culture as shared knowledge: Do data collection formats matter? Cultural knowledge of plant uses among Tsimane' Amerindians, Bolivia. Field Methods, 16(2), 135-156.

Sõukand, R. 2010. Herbal Landscape. Dissertationes Semioticae Universitatis Tartuensis, 14. Tartu University Press, Tartu.

Sõukand, R. \& Kalle, R. 2008. Historistlik Eesti Rahvameditsiini Botaaniline Andmebaas (HERBA) [HERBA, the Estonian Folk Medicine Database of Plant Use]. http://herba.folklore.ee 
Sõukand, R. \& Kalle, R. 2010a. Plant as object within herbal landscape: different kinds of perception. Biosemiotics, 3(3), 299-313.

Sõukand, R. \& Kalle, R. 2010b. Herbal landscape: the perception of the landscape as a source of medicinal plants. Trames, 14(64/59)(3), 207-226.

Sõukand, R. \& Kalle, R. 2011. Change in medical plant use in Estonian ethnomedicine: a historical comparison between 1888 and 1994. J. Ethnopharmacol., 135, 251-260.

Sõukand, R. \& Raal, A. 2008. How the name Arnica was borrowed into Estonian. Trames, 12(1), 29-39.

Svanberg, I., Łuczaj, J. L., Pardo-de-Santayana, M. \& Pieroni, A. 2011. History and current trends of ethnobiological research in Europe. In Ethnobiology (Anderson, E. N., Persall, D., Hunn, E. \& Turner, N. J., eds), pp. 191-214. Wiley-Blackwell, Chichester, UK.

Tardìo, J. \& Pardo-de-Santayana, M. 2008. Cultural importance indices: a comparative analysis based on the useful wild plants of southern Cantabria (Northern Spain). Econ. Bot., 62, 24-39.

Thomas, E., Vandebroek, I., Van Damme, P., Goetghebeur, P., Douterlungne, D., Sanca, S. \& Arrazola, S. 2009. The relation between accessibility, diversity and indigenous valuation of vegetation in the Bolivian Andes. J. Arid Environ., 73(9), 854-861.

Tolman, E. C. 1948. Cognitive maps in rats and men. Psychol. Rev., 55(4), 189-208.

Vandebroek, I. 2010. The dual intracultural and intercultural relationship between medicinal plant knowledge and consensus. Econ. Bot., 64(4), 303-317.

Vandebroek, I., Van Damme, P., Van Puyveldeb, L., Arrazolac, S. \& De Kimpe, N. 2004. A comparison of traditional healers' medicinal plant knowledge in the Bolivian Andes and Amazon. Soc. Sci. Med., 59, 837-849.

Waldstein, A. \& Adams, C. 2006. The interface between medical anthropology and medical ethnobiology. J. Royal Anthropol. Inst., 12(1), 95-118.

\section{Isiklik ja jagatud: erinevate ravimtaimemaastike ulatus}

\section{Renata Sõukand ja Raivo Kalle}

Ravimtaimemaastiku mudeli abil on analüüsitud Ambla ja Järva-Madise kihelkonna elanike ravimtaimede kasutust 1930. aastatel, aluseks on võetud Teet Luntsu saadetis botaanik Gustav Vilbastele. Uurimus põhineb arhiivitekstidel, mis kajastavad 11 õpilase ja 5 täiskasvanu pärimusliku taimravi alaseid teadmisi. On võrreldud üksikisiku kompetentsi kogukonna üldteadmistega. See ühine teadmine on edasi antud kogukonnasiseselt ühelt põlvkonnalt teisele (ökokultuuriline ühisosa), kuid jaotub ebaühtlaselt kogukonna liikmete vahel. Analüüsi tulemusena tuvastati 65 taime- ja 3 seeneliigi või perekonna kasutus 49 rahvapärase haiguse raviks. Edasine analüüs näitas teadmise jagunemist üksikisikute vahel kogukonnas ja selle võimalikke edasikandumise viise. Iga üksiku korrespondendi vastused olid isikupärased ja selgus palju taimi, mille kasutus oli teada vaid üksikutele vastajatele. Sellegipoolest järgis kogukondliku ravimtaimemaastiku muster võrdlemisi hästi, mõne erandiga, üldist ravimtaimede tundmist samal ajavahemikul. Võib öelda, et iga isik osaleb ökokultuurilise ühisosa hoidmises ja edasikandmises, samas ei valda üks inimene kunagi kogu kogukondlikku teadmist. 